\title{
FEELINGS OF WOMEN AFTER THE DIAGNOSIS OF TYPE 2 DIABETES ${ }^{1}$
}

\author{
Denise Siqueira Péres ${ }^{2}$ \\ Laércio Joel Franco $^{3}$ \\ Manoel Antônio dos Santos ${ }^{4}$
}

Péres DS, Franco LJ, Santos MA. Feelings of women after the diagnosis of type 2 diabetes. Rev Latino-am Enfermagem 2008 janeiro-fevereiro; 16(1):101-8.

Descriptive and exploratory study with the objective of knowing feelings and emotional reactions of women after the diagnosis of diabetes. Data were collected at a primary health care unit in Ribeirão Preto - SP, Brazil, through a semi-structured interview. Thematic content analysis was used for interpreting the data. The results showed that women's behavior after the diagnosis of diabetes was associated with feelings and emotional reactions that interfere with treatment adherence and which the health team needs to understand. In an educational process, it is not enough to offer information. Human behavior is extremely complex, going beyond the cognitive aspects, and is rooted in affective-emotional dispositions.

DESCRIPTORS: diabetes mellitus, type 2; emotions; health education

\section{LOS SENTIMIENTOS DE LAS MUJERES DESPUÉS DEL DIAGNÓSTICO DE DIABETES TIPO 2}

Se trata de un estudio descriptivo y exploratorio que tiene el objetivo de conocer las sensaciones y las reacciones emocionales de las mujeres después del diagnóstico de la diabetes. Los datos fueron recogidos en una unidad primaria de cuidado médico de la ciudad de Ribeiron Preto, SP, Brasil, durante una entrevista semiestructurada. El análisis del contenido temático fue utilizado para interpretar los datos. Los resultados demostraron que el comportamiento de las mujeres después del diagnóstico de la diabetes fue asociado a una serie de sensaciones $y$ de reacciones que interfieren en la adherencia al tratamiento y necesitan ser entendidas por el equipo de salud. En un proceso educativo, no basta con ofrecer información, porque el comportamiento humano es extremadamente complejo, yendo más allá de los aspectos cognoscitivos, y está arraigado en las esferas afectivas y emocionales.

DESCRIPTORES: diabetes mellitus tipo 2; emociones; educación en salud

\section{SENTIMENTOS DE MULHERES APÓS O DIAGNÓSTICO DE DIABETES TIPO 2}

Este estudo é de caráter descritivo-exploratório com o objetivo de conhecer os sentimentos e reações emocionais de mulheres com diabetes após o diagnóstico dessa enfermidade. Os dados foram coletados em uma unidade básica de saúde do município de Ribeirão Preto, SP, Brasil, por meio de entrevista semi-estruturada. Para análise dos dados, utilizou-se a análise temática de conteúdo. Os resultados mostraram que os comportamentos das mulheres, após o diagnóstico de diabetes, estavam associados a uma série de sentimentos e reações que interferem na adesão a tratamento e precisam ser compreendidos pela equipe de saúde. Em um processo educativo não é suficiente oferecer informações, pois o comportamento humano é extremamente complexo e transcende os aspectos cognitivos, enraizando-se também nas disposições afetivo-emocionais.

DESCRITORES: diabetes mellitus tipo 2; emoções; educação em saúde

${ }^{1}$ Paper extracted from the Master's Thesis. Research funded by FAPESP; ${ }^{2}$ Psychologist, M.Sc. in Medical Sciences, e-mail: desiperes@ig.com.br; ${ }^{3}$ Full Professor, University of São Paulo at Ribeirão Preto Medical School, e-mail: Ifranco@fmrp.usp.br; ${ }^{4}$ Ph.D., Faculty, University of São Paulo at Ribeirão Preto School of Sciences and Languages, Brasil, e-mail: masantos@ffclrp.usp.br 


\section{INTRODUCTION}

$\boldsymbol{D}$ iabetes is a syndrome characterized by chronic hyperglycemia, resulting from lack of insulin and/or its inability to function appropriately. It is a disorder in the metabolism of carbohydrates, lipids and proteins. The treatment for this disease is quite specific and complex. It involves maintaining an appropriate diet, doing physical exercises, quit smoking, using proper medication when necessary oral hypoglycemic agents and/or insulin, and performing glycemic self-control.

The treatment for diabetes requires permanent changes in patients' lifestyle. It implies living with a chronic condition that can be very threatening because it affects life as a whole, posing dramatic changes to the everyday lives of diabetics and their relatives ${ }^{(1)}$. Hence, it may arouse emotions like fear, guilt, shame, anger, weariness and regret ${ }^{(2)}$.

Feelings and emotions are a part of life and unquestionably affect it. As such, it also affects making the decision to comply or not with the instructions provided by health care professionals. Apparently, the psychosocial discomfort resulting from the impact of the disease and its daily treatment makes it difficult for patients to comply with some basic recommendations, such as glycemic self-control, a factor that is essential for an effective treatment ${ }^{(3)}$.

Being healthy does not merely regard one's physical body, but also one's emotions, which is a fundamental aspect that apparently affects how patients adjust to their disease. There is growing evidence that current health problems are not solved with health care procedures that focus exclusively on biological aspects: "(...) considering the current dominant diseases, such as chronic diseases (...), medicine has not proven to be as effective as it once occurred with infectious illnesses" ${ }^{\prime(4)}$.

There is no question that contributions of the biologic body of knowledge to the health field are extremely important. However, they are insufficient if used alone. Patients' emotional reactions to their illness are just as important as their physiological data. Thus, there is a need to consider psychological, cultural, economic and social aspects in the healthdisease process, since they affect patient behavior when having to deal with a chronic disease ${ }^{(5)}$.

People with any sort of physical impairment are influenced by emotional aspects, because the disease causes fragility. Psychological aspects, on the other hand, may have an intensifying effect on chronic illnesses like diabetes, and are associated with an increase in the risk of showing anxiety and depression symptoms $^{(6-7)}$.

Some studies show that the psychological profile and acceptance of the disease affect glycemic levels ${ }^{(8-9)}$ and can often compromise the life condition of people with diabetes, due to functional limitations, financial hardship, stress and depression ${ }^{(10)}$. In turn, the depressive state can cause decreased motivation to comply with the treatment, thus impairing glycemic control.

The diabetes diagnosis usually involves various feelings and emotional reactions which the health team should be able to manage and understand. Health care professionals should be prepared to offer support to all those in need. In addition, they should encourage patients to speak up about their feelings, listen to them, and provide a space in which patients feel welcomed, comfortable and safe to be in contact with intense, usually unpleasant emotions which they usually avoid, due to the high level of suffering they cause.

The objective of this study is to learn about the feelings and emotional reactions of women after the diagnosis of type 2 diabetes. This study is justified since it can contribute with reflections that lead to a more efficient and humanized care, seeking to provide integral care to people with diabetes.

\section{THEORETICAL-METHODOLOGICAL FRAMEWORK}

For the theoretical grounding of the present study, some classical concepts were adapted to diabetes, which were proposed for the chronic illness process ${ }^{(12)}$. Hence, after diagnosis and throughout the evolution of a serious, chronic and degenerative disease, patients usually go through some phases before accepting it. Those phases are: denial, rage/ anger, bargaining, depression and acceptance. It is important to emphasize that these phases are dynamic; that is, they can alternate, and an individual who has reached the acceptance phase of the diagnosis at a certain moment can recede to previous phases. The use of denial ( $1^{\text {st }}$ phase) shows a difficulty to face reality, and could appear due to an unexpected and shocking diagnosis - a chronic disease. Hence, patients can deny the disease or part of the recommended treatment. When it is no longer possible to use denial, 
feelings like rage and anger arise ( $2^{\text {nd }}$ phase), which can extend to the family, health team and friends. The $3^{\text {rd }}$ phase is bargaining, and the most noticeable characteristic is that the patients try to negotiate with health professionals, or with their family and friends, trying to gain some advantage over the illness, as a solution for the suffering it has caused. Regarding depression ( $4^{\text {th }}$ phase), the dominant feeling is loss, followed by intense sadness. When patients start to recognize that, besides the losses, there have also been gains throughout the disease process, they enter the $5^{\text {th }}$ phase - acceptance. Acceptance results from a gradual change in behavior, generating improved awareness and adaptations regarding the disease, and leading to an increased responsibility for their overall health condition. Patients in this phase find a certain inner peace, which favors acceptance and adaptation to their condition ${ }^{(12)}$.

Study participants

This is a descriptive, exploratory study, based on a qualitative approach. Patient selection, through their files, took place according to the following criteria: women; diagnosed for type 2 diabetes mellitus for at least one year; users of a Basic Health Unit in the city of Ribeirão Preto (São Paulo State); no psychiatric and/or mental disorders that would impair their communication abilities; agreement to participate in the research through written consent. Therefore, it is a convenience sample. Data saturation $^{(13)}$ was used to determine the number of study participants, which was achieved with eight interviews. The decision to perform the study exclusively with women was made for the sake of greater homogeneity, considering the gender differences in the behavior expressed towards the diagnosis of the disease. Moreover, historically speaking, women seek health services more often than men, and women often pass on health maintenance knowledge and practices within the family environment, since they care for the health of their relatives, neighbors and friends.

Location

Data collection occurred at the "Oswaldo Cruz Basic Health Unit", located in the neighborhood Vila Mariana. This location was chosen because the leading researcher had already had contact with that Health
Unit in the year 2000, through a Development Course on Hypertension and Diabetes, sponsored by the Ribeirão Preto Municipal Health Secretariat.

Data collection instrument

Semi-structured interviews were the chosen instrument, since this kind of interview grants the interviewee greater freedom and spontaneity, which is important to enrich the investigation. A guide was developed to direct the interviews, based on a literature review and considering the research objectives. This guide was subject to a pretest with two women with type 2 diabetes, and proved adequate for the study population.

Procedure for data collection and analysis

Data collection took place in January 2003 and participant selection was random, through a raffle performed with the patient files from the Health Unit, previously selected by diagnosis category. For each raffle, it was verified if the patient met the inclusion criteria. The researcher contacted the people who qualified, by phone or mail, explained the research purposes, and asked for the best date and hour for their visit to the Health Unit, respecting the users' availability. The face-to-face interviews were held at the Health Unit, in the psychology exam room, and lasted an average of 50 minutes. The data were taperecorded and immediately transcribed, fully and literally, and then subject to thematic content analysis. This analysis mode is considered "one of the forms that better adjusts to the qualitative investigation of health material", unfolding into three phases ${ }^{(13)}$ :

a) Pre-analysis: first, the interviews were literally transcribed and the collected material was read many times. This allowed for exhaustive contact with the data, becoming impregnated by its content. "Hypothesis" and objectives concerning the analyzed material were created, and the register unit (word, theme or phrase) as well as the context unit (delimitation of the context for understanding the register unit) were determined.

b) Exploring the material: This was the moment to apply what had been learnt in the previous phase. In this phase, the text was divided into register units (previously chosen), a code was determined for those register units, and the data were categorized and grouped into thematic units. 
c) Treatment and interpretation of the obtained results: The information obtained through the analysis was emphasized and permitted inferences and interpretations based on the adopted theoretical framework, with a view to disclosing the underlying content of the statements. The obtained data were also articulated with the available literature.

Ethics

The research project was approved by the Review Board at the Ribeirão Preto Faculty of Medicine Clinics Hospital in 4/14/2002 (process number 2689/ 2002). To guarantee participant anonymity and secrecy, the names used in the present report are fictional and the interviews occurred after the participants received sufficient clarification about their rights as volunteers, as well as about the study objectives. All participants provided written consent.

\section{RESULTS: GIVING USERS A CHANCE TO SPEAK}

The women who participated in the study were between 49 and 76 years old. They had a low educational level - less than $4^{\text {th }}$ grade of basic education. Regarding remuneration, the family income reported by five interviewees was below two minimum salaries, while the highest wage was three minimum salaries. As to their occupation, most were housewives.

Feelings and emotional reactions

Several reports evidenced feelings and reactions the interviewees experienced immediately after their diabetes diagnosis, like "rage", "anger", "sadness", "fear", "shock", and "fright". However, the statements show that, over time, they became used to having a chronic disease, in this case diabetes.

Oh, I was really angry (...) And it wasn't only me, the people in my family too, because I really liked sweets and since they took sweets away from me, I even cried (...) At that time I was very angry, but then I started to get used to it. Nowadays I don't care any more (Maria).

Oh, I wasn't well at all. My husband was worse, he even cried (...) I felt sorry for myself, but what could I do? (Ana). We take a scare, you know. You think it's overwhelming, and that you won't be cured. Well, actually, you really aren't cured, right? But you can improve, get better, you know? (Lucia).
Oh, I was very sad, you know, because my father-inlaw also had it. He died from diabetes, so I was very shocked (...) I was very sad, I started crying (Vera).

The statements show that, over time, the women began to accept their condition, stating they had accepted their disease and that diabetes no longer worried them.

Nowadays, I don't care any more, it has been 16 years, and I haven't died yet. If I last another 16 years, it's good enough, isn't it? I thing it's great! (...) I think that, for me, having diabetes is a normal thing. I have no problems living with it (Maria).

Now I don't care anymore, it doesn't bother me (...) Now I don't have any feelings, nothing. What am I to do, there is no solution anyway (...) For me, knowing it is like a person who doesn't have diabetes (Laura).

Yeah, but I don't worry about diabetes, not a bit (...) I travel, I look after the kids, I don't worry about the diabetes, because if I worry too much, then it gets worse. Then I really get sick. Now, if I don't think about it too much, I don't get sick (Ana).

I do things like I don't have anything, I don't (...) I live my life as if I didn't have anything (...) There are times when I worry, but most of the time I don't. What can I do, there isn't a cure anyway, right? So let's just move on the way we can, right? (Lucia).

One interviewee stated that she accepted the disease, because she did not follow the treatment very strictly, since she ate whatever she felt like. She also answered that, in case she worried about the disease, she could then follow the prescribed treatment more appropriately.

Oh, I don't have any feelings in this regard (...) I accept the disease (...) Some people say: no, I can't eat this, I won't eat it, and they don't. Not me, I say: I have diabetes, I want to eat a little, just a little won't do any harm (...) I don't worry about the disease, because if I did, maybe I would take better care of myself, right? (...) So I think: well, you're going to die anyway, so I'm not going to worry about this disease (Joana).

One statement evidenced the idea that diabetes is a disease that does not cause any pain, does not affect one's "nervousness", and does not affect people much, as long as they know how to control their glycemia.

It is a disease that doesn't affect us much, it doesn't hurt much, if you know how to control it (...) You don't feel pain, you don't feel nervous, you don't feel anything (...) You just have to avoid eating things with too much sugar (Nair).

One interviewee said she felt nervous when her diabetes was high. Another report showed that diabetes, along with aging, caused some 
discouragement. Some statements reported the fear of further complications due to diabetes.

I get nervous (...) because my diabetes is high (Nair).

I feel, like, discouraged (...) I think that is it because of my age and because of the diabetes too, you know. Because of both (Lucia).

I'm afraid of death by entering a coma, it happens to a lot of people. It is an annoying disease [laughter] (Ana).

For me, diabetes is a terrible disease. I think it is terrible. I even avoid getting my fingers hurt, I avoid chopping (...) I'm afraid it won't heal, if I cut my finger (...) I became miserable because of this disease, you know. It ruins a person's health (Claudia).

It was possible to notice the effect that emotions have on treatment compliance, as well as on the use of medication and maintaining the diet.

Yes, I think that if you keep calm, you won't have it. But if you feel uneasy all the time (...) because of that nervousness, sometimes you don't take the right medicine, you don't eat the right diet (Laura).

My brother is 80 years old, 80 , but he walks everyday. You know, he wants to live. Now I don't want to live anymore, he does (...) He says he doesn't drink anything with sugar, he doesn't drink soda, doesn't eat cake (...) When he told me, I was eating all those things (...) He said: do like I do. He uses sweetener, so then I started buying sweeteners and do what he's doing, you know. I quit drinking soda. My daughter bakes cakes, but I don't eat any. I eat, like, crackers, you know, cream crackers. I'm even sick of it (Claudia).

\section{DISCUSSION: FROM REALITY TO LITERATURE}

Adjusting to a chronic non-transmissible disease involves several changes to one's lifestyle. This affects people's everyday lives, and appears to be extremely distressing and difficult. Being diagnosed with a chronic disease like diabetes triggers several feelings, emotional reactions and fantasies, which health professionals should know and understand.

The data show that the diabetes diagnosis was accompanied by experiences loaded with dysphoric feelings like "sadness", "rage", "anger", "shock" and "fright". Some interviewees clearly stated that they experienced feelings of rage and anger after receiving their diabetes diagnosis. These feelings are signs of the existence of strong psychological conflicts that increase their vulnerability to symptoms of stress, depression and anxiety.
Patients in this phase (rage/anger) can present rebel behaviors and a constant question: "why did this happen to me?". In this phase, patients often complain about everything, they think nothing is good, and can become demanding, irritable and hostile. One statement that could exemplify this phase is: "I hate being diabetic". It is believed that this feeling of rage/ hate can draw patients away from everything that reminds them of diabetes and its treatment, and, thus, forget to take their medication, and, at some moments, eat with no control, as if the diabetes simply did not exist ${ }^{(12)}$.

The rage and hate patients feel can extend in all directions, including their own family and friends and healthcare professionals. Therefore, it may become quite difficult for all those close to the patients to tolerate their expressions of anger and hostility.

When dealing with a patient in this phase, health professionals should pay close attention to his/ her own feelings triggered by being in contact with the turbulent emotions of those living with the disease. It is important to be careful with contra transference; that is, not react to the patient's anger with an even stronger hostile manifestation due to the unconscious feelings experienced when one gets in contact with the patient's emotional universe. It is worth stressing that health professionals can express their anger in many different forms; for instance, avoiding contact with a certain patient by offering quicker care. One of the ways to learn how to deal with these patients' feelings is by trying to understand them, putting themselves in the place of the patient by means of a posture of unconditional acceptance and empathic understanding. For example, professionals should question themselves: if I were around 50 years old, hated doing physical exercises and taking medications every day, and loved to eat sweets, would I not, at some moment, also feel angry for having to live with the diabetes diagnosis. Regarding the strategy of putting yourself in the place of others, one could state that: "Diabetic individuals should be allowed to be who they are, we should withhold our personal beliefs, values and prejudice. We should put ourselves in their shoes and look through their eyes, and this way, only this way, will we understand these human beings we wish to know and exchange experiences with ${ }^{(14) "}$.

In order to help patients overcome this phase quicker and with less distress, it is important that health professionals dedicate part of their time to effectively listen to what those patients have to say 
and support any irrational rage that may exits, knowing that the relief resulting from speaking up will contribute to a better acceptance of their disease ${ }^{(12)}$.

Some interviewees reported experiencing sadness shortly after becoming aware that diabetes was present in their lives. In the depression phase, patients regret everything and life seems to loose its value. The feeling of rage gives place to a feeling of loss and deep sadness ${ }^{(12)}$, because life seems to have lost its sense. From the patients' view, the chronic health condition brings about numerous harms: loss in social relationships, financial losses, physical impairments, limitations to leisure activities and to the pleasure of smoking and drinking.

The disease can lead to social isolation and be highly destructive. On the other hand, however, it can also trigger positive feelings and bonding with others, strengthening ties of solidarity and support among friends, family members and even among strangers ${ }^{(15)}$. When patients begin to foresee that, besides the effective losses, there were also gains and benefits - in quality of life for instance - they gradually enter the final phase, which corresponds to accepting the disease.

If health professionals support patients regarding their suffering, pain and sadness, later on, when alone, these patients will have more strength to accept their disease as an inevitable limit of their human condition - and not as some kind of punishment or fatality. If professionals allow their patients to express their sadness, they will accept their situation more easily ${ }^{(12)}$.

Many years after the diagnosis, the lack of worries towards the disease and a certain conformism recurrently appear in the statements. In capitalist societies, one who suffers from a disease cannot stay ill for a long time, because being ill is a socially bearable state only for a short period. Thus, the patient may become indifferent, ignore or even deny the existence of the disease. People frequently have an image of their own body as a perfectly healthy organism. Denial happens when people cannot change their personal image.

There are two forms of denial: total and partial. Patients in a movement of total denial act as if they had never been diagnosed with diabetes, since they maintain the same eating habits, perform no physical activity and do not take their medications regularly. They often think that the doctor was mistaken about their diagnosis and that their exam results are wrong, or switched. One statement that can illustrate this phase is: "no, not me, it can't be true". Or yet: "for me, diabetes is not a disease". No case of total denial was identified in the interviews. The interviewees recognized that they were diabetic and did not deny the existence of their disease.

In partial denial, the patients deny one part of the reality or treatment. This way, they try to fool themselves by suppressing a part of reality that is associated with what causes suffering and distress. For example, one user, during the interview, denies that certain foods, even if in small amounts, could harm her health: "I have diabetes, I want to eat a little, just a little won't do any harm".

Denial is a defense of the individual's selfesteem, threatened by the irruption of the disease. It is worth remembering that all sorts of defense have a negative and a positive side. The negative side is that, using denial as a defense, it becomes more difficult for the patient to comply with the treatment. The positive aspect is that every defense has the purpose of defending the patient, for example, against experiencing any suffering or distress considered unbearable at that moment. Sometimes, patients might not be able to bear the diagnosis of a chronic disease and denial serves as a buffer to unexpected and shocking news that has a strong impact on people's everyday lives and self-image. When reality is too harsh, many patients use denial as if they need some extra time to absorb the emotional impact and elaborate the traumatic experience, with the purpose of building the strength to deal with the disease more adequately.

Health professionals should always search for a balance in their attitudes: they should be realistic but also respect patients when they show signs that they can no longer tolerate the harsh reality of having a chronic disease. Health professionals should constantly ask themselves: what is the patient's need, and what is my actual availability to help him/her right now?

Diabetes can arouse fantasies, fears and anxieties that pose obstacles to information incorporation and treatment compliance. It is known that, at moments of great anxiety, the capacity to absorb information is impaired. There are obstacles in the teaching-learning process, both cognitive and emotional, which the health team needs to understand and develop. 
Diabetes is often an asymptomatic painless disease and permits patients to maintain their normal daily activities, which favors reactions and magical thoughts like: "for me, it's like being a person without diabetes"; "I don't care, you know"; "I act as if I don't have it".

Concurrently, some statements showed there is a restlessness feeling when glycemic levels are high, which increases the fear of complications due to diabetes. This can help in the search for improved metabolic control.

Generally, the experienced feelings appear contradictory and ambiguous; hence, some statements show the obstinacy to live as if the diabetes did not exist or was not a problem in their lives. This tendency coexists with attitudes unveiled in other statements, which reveal a "terrible", "nervous", "sad", "discouraged" life experience, with permanent "fear" of the complications diabetes can cause. The negative perception towards diabetes can also be associated with the fact that some healthcare professionals excessively emphasize prohibitions. Patients might understand this attitude as "nothing is permitted" and, thus, it creates a rather dark and desolating perspective towards living with a disease that appears to subtract the pleasure of living. Interventions that support the possibility of preserving the essence of life, despite the restrictions imposed to their everyday life, could be much more functional.

The statements clearly show how emotions affect treatment compliance and disease self-control. People with diabetes make decisions regarding the treatment for this disease that affect and are affected by their feelings, thoughts, values and other psychosocial aspects that predispose to actions ${ }^{(15)}$.

The statements show an association between not complying with treatment and what a patient referred to as "not wanting to live". This data suggest that, in cases of chronic conditions, patients need to want to live and hope to achieve a better symptom control. In other words, every dimension of the diabetic patient's life should be considered, from the most trivial routine to the desire to continue fighting for life. People's desire and commitment to their own lives are fundamental elements in disease treatments ${ }^{(16)}$, particularly for chronic health conditions.

The interviewees experienced negative emotions due to prohibitions, limitations and possible complications caused by diabetes. It appears that they cannot bear to live the whole time with so many restrictions loaded with negative feelings. Therefore, they use denial as a means to find relief from the anxiety brought about by the feeling of uncontrol over the events that attack their organism. Hence, just like it is impossible to look at the sun all the time, one cannot face the disease the whole time"(12).

\section{FINAL CONSIDERATIONS}

Results show that patient behaviors in view of the diabetes diagnosis are associated with a series of feelings and emotional reactions the multidisciplinary health team should understand. As evidenced through the interviewed women's statements, the diagnosis arouses a range of emotional responses. Health professionals should, therefore, have the ability to support diabetic patients in effectively dealing with the underlying aspects of the disease. This way, it is possible to achieve greater adaptive efficacy. Thus, it is clear that simply offering information is not enough, because human behavior is extremely complex and transcends merely cognitive aspects, also based on the affectiveemotional dispositions and values that ground people's attitudes and behaviors.

Literature has shown that, though it is necessary to provide information, it is neither sufficient to promote behavior changes, nor does it guarantee better glycemic control. Moreover, an increase in the amount of information provided does not necessarily correspond to improved treatment compliance. However, there is still a general idea that the access to certain knowledge is, per se, capable of promoting changes in habits and lifestyles, considering the uncountable educational programs focused exclusively on knowledge dissemination.

It is very important to obtain accredited information and it can, indeed, help to prevent diseases and diabetes-associated complications, but it does not necessarily guarantee that there will be changes in the undesirable behaviors from the health promotion perspective. Providing information is not the single aspect involved in the complex relationship between knowing and doing, since emotional aspects act as mediators between information and its subjective elaboration that leads to the transformation of the learned information into knowledge for everyday living. This knowledge, continuously reelaborated by the patient based on his/her own life 
experiences, is what leads to behavior changes, permitting healthy life habits to be incorporated.

The obtained results offer relevant information for health practice. It is inferred that the acknowledge difficulty regarding diabetic patients' compliance with treatment as well as with the recommendations made by health professionals, broadly evidenced in literature, go deeper than the mere lack of information. We believe that, to achieve greater effectiveness, educational programs should be based on dialogue and on exchanging experiences, considering the triggered emotions, thus promoting a genuine interchange between scientific and popular knowledge. After all, health professionals and patients have much to teach and learn from one another.
The present study had some limitations, such as the need for studies involving patients with a broader sociodemographic and educational range, which were not comprised in the scope of this study. Another suggestion is to replicate this study with larger samples, so as to permit the comparison with qualitative contributions from the present research, which would favor the development of educational programs specific to the Brazilian reality.

The present study contributes to a better understanding of the emotional aspects involved in diabetes diagnosis and treatment. However, the results suggest that further studies are needed in order to explore other dimensions associated with the feelings and emotional reactions involved.

\section{REFERENCES}

1. Santos ECB, Zanetti ML, Otero LM, Santos MA. O cuidado sob a ótica do paciente diabético e de seu principal cuidador. Rev Latino-am Enfermagem 2005 maio-junho; 13(3):397-406. 2. Altschuler J. Working with adults who are ill. In: Altschuler J. Working with chronic illnes. United Kingdom: MacMillan; 1997. p. 127-55.

3. Delamater AM, Jacobson AJ, Anderson B. Psychosocial therapies in diabetes. Diabetes Care 2001; 24:1286-92.

4. Adam P, Herzlich C. Sociologia da doença e da medicina. Bauru (SP): EDUSC; 2001.

5. Mercado-Martinez FJ, Silva LR, Herrera IMR, Leal NM, Hernández EA. La perspectiva de los sujeitos enfermos. Reflexiones sobre pasado, presente $Y$ futuro de la experiência del padecimento crônico. Cad Saúde Pública 1999; 15(1):179-86.

6. Gameiro F, Moos EC, Teixeira JAC. Satisfação de sujeitos diabéticos em relação aos cuidados de saúde. In: Ribeiro JL, Leal I, Dias MR. Psicologia da saúde nas doenças crônicas. Lisboa: Instituto Superior de Psicologia Aplicada; 2000. p. 297-310

7. Peyrot M, Rubin RR. Levels and risks of depression and anxiety symptomatology among diabetic adults. Diabetes Care 1997; 20(4):585-90.

8. Polonsky WH, Anderson BJ, Loher PA. Assessment of diabetes-specific distress. Diabetes Care 1996; 18:75460.

9. Maia FFR, Araújo LR. Aspectos psicológicos e controle glicêmico de um grupo de pacientes com diabetes mellitus tipo 1 em Minas Gerais. Arq Bras Endocrinol Metab 2004; 48(2):261-6

10. Anderson RM Funnelk MM, Barr PA, Dedrick RF, Davis WK. Learning to empower patients: results of professional education program for diabetes educators. Diabetes Care $1991 ; 14(7): 584-90$
11. Doherty $Y$, James $P$, Roberts $S$. Stage of change counselling. In: Frank S, Skinner T. Psychology in diabetes care. England: John Wiley; 2000. p. 100-39.

12. Kübler-Ross E. Sobre a morte e o morrer. São Paulo (SP): Martins Fontes; 1994

13. Minayo MCS. O desafio do conhecimento: pesquisa qualitativa em saúde. São Paulo (SP): Hucitec; 1994.

14. Santana MG. O corpo do ser diabético, significados e subjetividade. [Tese]. Florianópolis: Centro de Ciências da Saúde/UFSC; 1998.

15. Peres DS, Franco LJ, Santos MA. Comportamento alimentar em mulheres portadoras de diabetes tipo 2: o sentir, o pensar e o agir. Rev de Saúde Pública 2006; 40(2):310-7. 16. Berlinguer G. A doença. São Paulo (SP): Hucitec; 1988. 